\title{
Views of the Pre-service Classroom Teachers about Technology Literacy
}

\author{
Selcen Süheyla Ergün ${ }^{1, *}$, Nuray Kurtdede Fidan ${ }^{1}$, Nuray Yildirim² \\ ${ }^{1}$ Faculty of Education, Afyon Kocatepe University, Turkey \\ ${ }^{2}$ Sandiklı School of Applied Sciences, Afyon Kocatepe University, Turkey
}

Copyright $\odot 2019$ by authors, all rights reserved. Authors agree that this article remains permanently open access under the terms of the Creative Commons Attribution License 4.0 International License

\begin{abstract}
Technology literacy can be defined as the whole of the intellectual process, competence and order that individuals need to understand about the relationship between technology and themselves and society. An individual with technology literacy can question technological processes and innovations critically. The aim of this research is to examine the views of the pre-service classroom teachers about technology literacy. The participants of the study are 160 pre-service classroom teachers attending Afyon Kocatepe University. Of them eighty were third grade students and the remaining eighty were fourth grade students. The data of the study were collected through the administration of a survey questionnaire with six open-ended items which was developed by the authors. The data obtained were analysed using the descriptive statistics. The findings are given in tables and discussed. The findings indicate that most of the participants actively use technology and that they often tend to use it in the courses. The participants reported that they could use technological devices more in the courses of social studies, science and life sciences. It is emphasized that the correct use of technological tools can lead to desirable results, but the incorrect use of technological devices may produce undesirable results and that technology should be used consciously.
\end{abstract}

Keywords Attitude towards Technology, Technology Education, Pre-service Classroom Teachers

\section{Introduction}

Technology has been a growing phenomenon since the existence of humanity. The technology that emerged as a result of science made our life easier in every field and saved time. In order to meet the needs of individuals who produce something, share it with others, are self-confident and have necessary skills and information about communication and information technologies and are sensitive to the events technology should be used effectively [1]. People are faced with new technological tools and equipment almost every day. It is very important for individuals to perceive the benefits of such tools and equipment to humanity and to be able to use them for their own needs. Therefore, individuals should be trained to be familiar with technologies through formal and informal education to adapt technological innovations in their daily life [2]. Individuals need to be equipped with modern knowledge, skills and attitudes in order to keep pace with rapidly developing technology and increasingly complex society. The aim of technology education is to enable individuals to understand the dynamic power of technology and to help individuals to use technology in the most efficient way. Technology education becomes important in this context [3]. Technology education is a technological study that provides students with the opportunity to learn about technology-related processes and knowledge needed to solve problems and increase their abilities. The ability to design, develop, manufacture, use, select and maintain technological production is an important component of technology education [4]. The advancement of technology has changed the characteristics of the individual needed by the society. As a result, educational institutions with the largest share in the education of individuals are given great responsibilities, and the concept of literacy has emerged in the field of education. The concept of literacy has had many different meanings over time. In the 21st century, the concept of literacy has expanded, and new literacy types have emerged in line with the needs. One of these literacy types is technology literacy [5]. Considering the literacy concept which emerged as a mandatory requirement of the age of information and technology, it is safe to argue that one of the important types of literacy is technology literacy. Understanding of the technology by the individuals who make up the society is important in terms of enabling them to understand their relations with the society easily [6]. The International Technology Education Association defines technology literacy as the ability to use, manage, evaluate and understand technology [4]. Technology literate 
individuals are expected to be aware of and have information about how technology affects and is affected from society as well as they are expected to be aware of what they can do with technology. The aim of technology literacy is to help students to achieve, adapt, understand, explore and develop their skills of adaptation to current situations and future technology societies at all stages of education [7]. In our world where technology is used in every field, being a technology literate in general and information technology literate in particular is very important for both society and the individual. To understand the dimensions and limits of technology and to know about the possibilities and problems caused by it is an important obligation of being a citizen. Being aware of the existing technologies with critical and critical thinking skills in the globalized world and having the ability to use these technologies in line with the objectives and needs stated is the most important duty of global citizens. Being a global citizen requires technology literate individuals to question technology [8]. As in all stages of our lives, technology also becomes increasingly popular in education. For this reason, education systems are renewed through the use of technology [9]. Every teacher must keep up with the current period to provide an effective education and instruction. Therefore, teachers are expected to use technology effectively and to be a good technology literate. In this way, it is aimed to educate well-educated individuals [10]. In order to achieve this goal, various technologies have been used for educational purposes. The use of technology in educational settings from past to present has been through technological tools such as overhead projector, computer, projection and smart boards. [11]. In order to achieve the desired success in the professional life pre-service teachers should have the ability to know and use the technology in education. Because the pre-service teachers will meet with students who are intertwined with technology when they start working. For this reason, all societies, especially the developed countries, are trying to bring quality education to individuals by using technology [12]. There are many studies conducted on this subject [13-19]. However, there is no study investigating prospective teachers' opinions about technology literacy in the literature. Therefore, the aim of this study is uncover the views of the pre-service teachers about technology literacy.

In this study, the following problem was sought: What are the views of the pre-service teachers about technology literacy?

\section{Method}

The study uses a descriptive method. Descriptive research deals with a topic as a whole or a part of it to have a general view about it which has many different elements [20]. Descriptive studies are used in situations where events, objects and other different areas are attempted to be described and explained [21]. The participants of the study are 160 third and fourth grade pre-service classroom teachers attending Afyon Kocatepe University.

The data of the study were collected through the administration of a survey questionnaire with six open-ended items which was developed by the authors. The survey questionnaire was reviewed by three field specialist to establish its construct validity. The questionnarie was used in a pilot study a sample of ten students. Based on the feedback from the pilot study the questionnaire was improved. Concerning the reliability of the questionnaire the data were coded by the authors and the coeffiecient was found to be $90.4 \%$ based on Miles Huberman's formula.

The following questions were asked to pre-service teachers via the measurement tool:

1. Do you see yourself as a technology literate?(yes/no)

2. What does technology literacy mean? Please explain.

3. How does the pre-service teachers have a technology literacy to contribute to his professional life?

4. How does the use of technology tools affect the individual's habit of doing research?

5. In which courses do you use technology tools more? Please explain.

6. Do you consider yourself a technology literate?

7. What should be done in order for pre-service teachers to become technology literate in the faculty of education?

The data were analyzed using the descriptive analysis method. The frequency and percentages of the data obtained are tabulated.

\section{Findings}

For the first item of the questionnaire, 'Do you regard yourself as a technology literate?' $45 \%$ of the participants provided positive answers. The rate of the participants who answered it negative is found to be $18 \%$. There were participants who stated that they are partly technology literate (37\%).

As can be seen in Table 1, $75 \%$ of the participants reported that they use effectively technology and $10 \%$ reported that they did not use it effectively. The remaining $15 \%$ did not state any views about it. It is seen that most of them thought themselves as effective users of technology.

Table 1. Views of the participants about efficient use of technology

\begin{tabular}{|c|c|c|}
\hline Views & $\mathrm{f}$ & $\%$ \\
\hline I use it effectively & 120 & 75 \\
\hline Null & 23 & 15 \\
\hline I don't use effectively & 17 & 10 \\
\hline
\end{tabular}

Table 2 shows that $55 \%$ defined technology literacy as using technology in a correct and effective way. The rate of the participants who defined it as following the 
technological advances is found to be $23 \%$. There were also participants who regarded it as using technology and technological devices consciously (13\%). Some of the participants considered it as individuals who make research and question (9\%).

Table 2. Views of the participants about technology literacy

\begin{tabular}{|c|c|c|}
\hline Views & $\mathrm{f}$ & $\%$ \\
\hline To use technology accurately and effectively & 106 & 55 \\
\hline To follow technological developments & 53 & 23 \\
\hline $\begin{array}{c}\text { To use technology and technological instruments } \\
\text { consciously }\end{array}$ & 27 & 13 \\
\hline Investigating, questioning individual & 10 & 9 \\
\hline
\end{tabular}

The majority of the participants stated that technology literacy is the use of technology in a correct and effective way. It is concluded that a pre-service teacher should use technology in a correct and efficient way and also, follow technological developments. The following statements show the views of the participants in this regard:

Individuals who follow and investigate technological developments and use technology as well as who are interested in these developments effectively. (PT 36)

It refers to use technology accurately and effectively. It refers to follow and keep up with the innovations brought by the current age and society. (PT 157)

As can be seen in Table 3 concerning the potential contributions of technological contributions to the participants' future professional life $25 \%$ of the participants argued that that technology would facilitate teaching, and another $25 \%$ of them reported that it would make it possible to deliver efficient education. There were some participants who stated that it has positive effects (15\%). The others argued that it would improve long-lasting learning (14\%), that it would make abstract notions concrete $(11 \%)$ and that it would improve the quality of education (9\%). There were some participants who reported that it would be a contemporary practice (1\%).

Table 3. Views of the participants about the contribution of technology literacy to their professional life

\begin{tabular}{|c|c|c|}
\hline Views & $\mathrm{f}$ & $\%$ \\
\hline Facilitates teaching. & 51 & 25 \\
\hline Provides effective training. & 51 & 25 \\
\hline Positive effects. & 31 & 15 \\
\hline Increases persistence in education. & 29 & 14 \\
\hline Emphasizes teaching. & 24 & 11 \\
\hline Improves quality in education. & 21 & 9 \\
\hline Provides a fit for the age. & 3 & 1 \\
\hline
\end{tabular}

The majority of the participants reported that technology would facilitate teaching and effective education. The fact that a teacher is a technology literate significantly affects his professional life in a positive way. It facilitates teaching, makes learning permanent and ensures active participation. The following statements show the views of the participants:

If a pre-service teacher is technology literate it will have positive effects on his future profession. Because the use of technology during the course facilitates teaching and ensures that the course is efficient. At the same time, students learn with fun. (PT 149)

It is very important for a teacher to be a technology literate. It provides both contributions to his professional life and to the learning of new knowledge. It makes the delivery of courses more productive and effective. (PT 81)

Table 4. Views of the participants about the positive and negative effects of using technology tools in regard to individual's doing research

\begin{tabular}{|c|c|c|}
\hline Positive effects & $\mathrm{f}$ & $\%$ \\
\hline It provides information in a short time and easy to reach. & 58 & 62 \\
\hline Gain the habit of doing research. & 23 & 22 \\
\hline He knows where to use the information. & 8 & 7 \\
\hline It provides a wide and different view. & 7 & 5 \\
\hline Increases students' sense of curiosity. & 6 & 4 \\
\hline Negative effects & & \\
\hline It pushes students to laziness and preparedness. & 40 & 60 \\
\hline It cannot avoid the harm of technology. & 27 & 30 \\
\hline Learn the wrong information. & 6 & 10 \\
\hline
\end{tabular}

Concerning the positive or negative effects of the use of technological devices on the habit of making research it was found that $60 \%$ of the participants has positive views (f:92). Among this participants who had positive views $62 \%$ reported that such devices makes it possible to access information fast and easily. In addition, $22 \%$ of them argued that the use of technological devices allows for users to gain a habit of making research. There were some participants who stated that through the use of such devices the users know where to use information (7\%). The others argued that it will make it possible to have an expanded and distinct perspective (5\%) and to improve the curiosity of students (4\%).

It has been argued that the use of technology equipment by the pre-service teachers contributes positively to their habit of doing research. They stated that when used in the right direction in terms of education and training technological devices will have positive results, and the technology has been argued to give individuals the desired habits of doing research.

It has positive effects. Technology enables faster access to information. At the same time it improves the ability ro make comparisons with different information and reasoning skills. (PT 87)

Technology is useful to reach information instantly and faster. But from time to time, technology can make individuals lazy, curtailing their research motivation.(PT 94) 
Concerning the advantages and disadvantages of using technological devices in relation to individuals' habits of making research $40 \%$ of the participants reported that it has negative effects (f:73). In addition, $60 \%$ of them reported that it may make students much lazier and free riders. There were also those who argued that technology would be harmful to students (30\%) and that they may access misinformation through technological devices (10\%).

Positive opinions were reported as well as negative opinions about the use of technology tools to inform the individual about the habit of doing research.

The participants argued that when technological devices are used correctly it will have positive results. However, if not, it may produce some undesired results. The following statements indicate the views of the participants:

Technology adversely may make individuals free-riders. But, it may positively make it possible to access information easily. (PT 90)

Technology is positive for some who can use it, but may be harmful for those who do not know how to use it. Technology causes us to prefer to easy ways. Therefore, if it is used consciously its use is positive. (PT 93)

Table 5. Views of the participants about the appropriateness of the use of technological devices for the courses

\begin{tabular}{|c|c|c|}
\hline Views & $\mathrm{f}$ & $\%$ \\
\hline All courses & 84 & 32 \\
\hline Social Studies course & 55 & 21 \\
\hline Science course & 50 & 19 \\
\hline Life Science course & 30 & 10 \\
\hline Mathematics course & 17 & 6 \\
\hline Turkish course & 17 & 6 \\
\hline Music course & 9 & 5 \\
\hline Physical education & 1 & 1 \\
\hline
\end{tabular}

Concerning the potential use of technological devices for the future courses $32 \%$ of the participants reported that they may use them for all courses. The rate of those who argued that they may use such devices for social studies courses is found to be $21 \%$. Nearly $19 \%$ of the participants reported that such devices can be used for science courses and $10 \%$ of them reported that the use of the technological devices is appropriate for the course of life sciences. There were also participants who reported that they may use them for the course of mathematics (6\%) and for the course of Turkish courses (6\%). It was also reported by them that technological devices can be employed for music courses (\%5).

Regarding the potential use of technological devices for the future courses they will teach the participants stated that the use of such devices will be much more appropriate for the courses of social studies, science and life science courses due to the fact that these courses mostly involve topics from real life. The following statements exemplify these views of the participants:

I think that I will use technological devices for all courses. However, because life science course have much more topics from daily life, I can use such devices for this course more than others. (PT 150)

I am planning to use technological devices in all courses. Since I will be a classroom teacher, I often need to apply to visual materials. I will do it using computers and slide projection. (PT 71)

Technological equipment can be used more effectively in the courses such as social studies and life sciences. Because these lessons include topics from life so that such equipment is more proper to use in these courses. (PT 107)

In fact, it can be used in all courses. However, it is much more proper for the courses of life sciences and mathematics. Life science is an appropriate course for using technology tools in that it includes real life news and events, and mathematics is also proper for it in that it includes some abstract concepts which should be made concrete. (PT 69)

Table 6. Views of the participants about what to do to improve technology literacy of pre-service teachers

\begin{tabular}{|c|c|c|}
\hline Views & $\mathbf{f}$ & $\mathbf{\%}$ \\
\hline $\begin{array}{c}\text { Technology and the productive use of technological } \\
\text { devices should be taught in the courses }\end{array}$ & 40 & 21 \\
\hline $\begin{array}{c}\text { There should be a course on technology literacy in the } \\
\text { teacher training programs }\end{array}$ & 35 & 18 \\
\hline $\begin{array}{c}\text { The courses on computers should be practical and given } \\
\text { importance }\end{array}$ & 28 & 14 \\
\hline $\begin{array}{c}\text { Including organizing seminars, conferences and other } \\
\text { activities to improve technology literacy of pre-service } \\
\text { teachers }\end{array}$ & 25 & 13 \\
\hline Using journals, Internet sources and newspapers & 22 & 11 \\
\hline Increasing the use of technology & 20 & 10 \\
\hline Using technology by educators in an efficient way & 15 & 8 \\
\hline Using the necessary hardware & 5 & 5 \\
\hline
\end{tabular}

In regard to improve technology literacy of pre-service teachers $21 \%$ of the participants argued that both technology and the productive use of technological devices should be taught in the courses. On the other hand, $18 \%$ of the participants reported that there should be a course on technology literacy in the teacher training programs. There were also participants who suggested that the courses on computers should be practical and given importance (14\%). There were other suggestions, including organizing seminars, conferences and other activities to improve technology literacy of pre-service teachers (13\%), using journals, Internet sources and newspapers (11\%), increasing the use of technology (10\%), using technology by educators in an efficient way (8\%) and using the necessary hardware (5\%).

The participants reported that in the courses the productive use of technological tools should be taught. The following statements exemplify such views:

Courses on technology use may be included in the teacher training programs. These courses should be carried out in a practical way. The use of technology in 
micro-teaching should be encouraged. (PT 94)

Pre-service teachers should follow technology and learn

how to use technology tools in lessons. (PT 18)

Teacher training programs may include a course called technology literacy. (PT 11)

\section{Discussion and Conclusions}

In this study the views of the pre-service classroom teachers were analysed in relation to the effective use of technology, technology literacy, the potential contributions of technology literacy to their professional life, the use of technology tools in conducting research, which courses are eligible for the use of technological equipment and tools and the improvement of technology literacy of pre-service teachers.

In regard to the effective use of technology $75 \%$ of the participants reported that they are effective users of technology. To keep up with the rapid development of technology in the education process both educational institutions and teachers as well as pre-service teachers should closely follow the changes $[18,22,23$. It becomes impossible to think about technology and education separately. For this reason, every pre-service teacher should use the technology effectively.

Concerning the definition of technology literacy $55 \%$ of them defined it as the correct and effective use of technology. The purpose of computers and related technologies is not to replace teachers in schools. Technology helps to have a more effective and productive school and to generate effective solutions to the barriers encountered. Training of teachers and especially that of school administrators who lead technology is required for effective use of technology in schools [24, 25]. Effective use of technology is important for everyone, including teachers, students and administrators at school. It is necessary to use technology correctly and effectively at every stage of education in order to produce individuals who can make research and question the topics as required by the age.

In regard to the potential contributions of technology literacy $25 \%$ of the participants argued that it would facilitate teaching, and another $25 \%$ of them reported that it would make it possible to deliver efficient education. Concerning the positive or negative effects of the use of technological devices on the habit of making research it was found that $60 \%$ of the participants has positive views arguing that such devices makes it possible to access information fast and easily.

Concerning the disadvantages of using technological devices in relation to individuals' habits of making research $40 \%$ of the participants reported that it has negative effects, arguing that it may make students much lazier and free riders.

Teachers, administrators, technical staff and all the students in the teaching process should be made aware of the effective use of technology in teaching. In this way, the existing and emerging technologies take the expected place in the educational activities. This positively affects the use of technological tools [26, 27].

Concerning the views of the participants about the use of technological devices and equipment in the courses in their future professional life they reported that they would use such equipment in all courses (32\%), in social studies courses $(21 \%)$, in science courses $(19 \%)$ and in life sciences courses (11\%).

Concerning the views of the participants about how technology literacy of pre-service teachers can be improved $21 \%$ of them reported that it should be improved through the productive use of technology and technological devices in courses. However, pre-service training is not sufficient to achieve this goal. Teachers should be given in-service training on the use of technology in order for them to follow the rapidly developing technological developments. Because the changes in education and the development of teachers are interdependent elements. For this reason, it is necessary to provide continuous support to teachers about professional development for qualified teachers and qualified educational activities [28, 29].

As a result, the majority of pre-service class teachers participated in the study supported the use of technology for educational purposes. In the current age of technology education cannot be considered independent of technology. In addition, it has been determined that the use of these technological tools whenever needed and in time is visually important and saves time. It is also required that technological devices should be used for desired goals. In a similar study it was stated that the perceptions of pre-service teachers about the use of technology in education is in positive way. It can be said that this positive perception affects the attitude towards teaching profession positively. At the same time, it was stated that this positive attitude towards technology use increased as the increasing technology literacy levels of the pre-service teachers [25, 30]. Technology helps individuals to use the knowledge and skills gained through education in a better and more efficient way and to apply them more consciously. These findings suggest that the attitudes of the pre-service classroom teachers towards technology improved positively.

\section{Suggestions}

Based on the findings of the study the following suggestions are developed:

Teachers should be provided with in-service and pre-service training to develop their skills in technology literacy in teaching in order to make effective use of technology tools as teaching and learning materials.

Pre-service classroom teachers should be informed 
about the courses in which the technological tools and equipment can be used and how it can be used in the courses for teaching and learning purposes.

Before giving information about which technology equipment should be used a pre-service teacher should be given a course under the name of technology literacy. Because a pre-service teacher who is not trained in technology cannot control the technology and therefore, cannot use technology efficiently in the courses.

\section{REFERENCES}

[1] A. Ünal, Analysis of perception on supervisors in primary education, World conference on Educational Sciences: Abstracts Book (s. 268). 4-8 February 2010, İstanbul: Bahcesehir Üniversitesi, 2010.

[2] S. Çepni, Bilim, fen, teknoloji ve eğitim programlarına yansimaları. Kuramdan uygulamaya fen ve teknoloji öğretimü, (Üçüncü Bask1), S. Çepni, (Ed.), Pegem-A Yayıncılık, Ankara, 2005.

[3] A. Şenel, , S. Gençoğlu, Küreselleşen dünyada teknoloji eğitimi, Gazi Üniversitesi Endüstriyel Sanatlar Eğitim Fakültesi Dergisi, 11(12), 45-65, 2003.

[4] International Technology Education Association and Technology for all Americans [ITEA], Standard for technological literacy, Reston, VA, International Technology Education Association, 2000.

[5] N. Canbaz, Yetișkin eğitimi kurslarına devam eden kadın kursiyerlerin teknoloji okuryazarlığı eğitim ihtiyacını belirleme, Yüksek Lisans Tezi, Çanakkale Onsekiz Mart Üniversitesi, Sosyal Bilimler Enstitüsü, Çanakkale, 2010.

[6] A. Bacanak, O. Karamustafaoğlu, S. Köse, A New View: Technology Literacy in Education, Pamukkale Üniversitesi Eğitim Fakültesi Dergisi, 2(14), 191-196, 2003.

[7] A. Y. L. Lee, Media Education: Definitions, Approaches and Development Around The Globe, New horizons in education, 2010.

[8] F. Odabaşı, Toplumsal Etkiler ve Teknoloji Okur Yazarlığı, In Education Conference In light of Information Technology (BITE 2000), in Middle East Technical University, Ankara, 2000.

[9] Ş. Karasar, Eğitimde Yeni İletişim Teknolojileri-İnternet ve Sanal Yüksek Eğitim-, Turkish Online Journal of Educational Technology, V. 3, I. 4, p. 117-125, 2004.

[10] F. Ulusoy, Kimya eğitiminde model uygulamalarının ve bilgisayar destekli öğretimin öğrenme ürünlerine etkisi: 12. sınıf kimyasal bağlar örneği. Sınıf Kimyasal Bağlar Örneği, Marmara Üniversitesi Eğitim Bilimleri Enstitüsü, (Yüksek lisans Tezi), İstanbul, 2011.

[11] S. Çiftçi, S.M. Taşkaya, M. Alemdar, The opinios of classroom teachers about Fatih project, Elementary Education Online, 12(1), 227-240, 2013.

[12] Milli Eğitim Bakanlığı [MEB], Temel Eğitim Projesi, II Faz Başlangıç Semineri, Ankara, 2004.
[13] N. Selwyn, Education and technology: Key issues and debates, Bloomsbury Publishing, 2016.

[14] C. Englund, A. D. Olofsson, L. Price, Teaching with technology in higher education: understanding conceptual change and development in practice, Higher Education Research \& Development, 36(1), 73-87, 2017.

[15] J. Tondeur, N. Pareja Roblin, J. van Braak, J. Voogt, S. Prestridge, Preparing beginning teachers for technology integration in education: ready for take-off?, Technology, Pedagogy and Education, 26(2), 157-177, 2017.

[16] A. Collins, R. Halverson, Rethinking education in the age of technology: The digital revolution and schooling in America, Teachers College Press, 2018.

[17] A. M. Güneş, B. Buluç, Sınıf Öğretmenlerinin Sınıf Yönetim Becerileri ve Teknoloji Kullanımları Arasındaki İlişki, Necatibey Eğitim Fakültesi Elektronik Fen ve Matematik Eğitimi Dergisi, 12(2), 739-771, 2018.

[18] M. Yilmaz, L. Üredi, S. Akbaşlı, Sınıf öğretmeni adaylarının bilgisayar yeterlilik düzeylerinin ve eğitimde teknoloji kullanımına yönelik algılarının belirlenmesi, Uluslararası Beşeri Bilimler ve Eğitim Dergisi, 1(1), 105-121, 2015.

[19] S. N. Şad, Ö.İ. Nalçaci, Öğretmen adaylarının eğitimde bilgi ve iletişim teknolojilerini kullanmaya ilişkin yeterlilik algıları, Mersin Üniversitesi Eğitim Fakültesi Dergisi, 11(1), 2015.

[20] N. Karasar, Bilimsel Araştırma Yöntemi, Ankara: Nobel Yayın, 26, 2014.

[21] A. Üstün, E. Bozkurt, İlköğretim Okulu Müdürlerinin Kendilerini Algılayışlarına Göre Problem Çözme Becerilerini Etkileyen Bazı Mesleki Faktörler, Kastamonu Eğitim Fakültesi Dergisi, 11(1), 13-20, 2003.

[22] S, Sadi, A. R. Şekerci, B. Kurban, F. B. Topu, T. Demirel, C. Tosun, et al., Öğretmen eğitimde teknolojinin etkin kullanımı: öğretim elemanları ve öğretmen adaylarının görüşleri, Bilişim Teknolojileri Dergisi, 1(3), 43-49, 2008.

[23] S. S. Seferoğlu, Okullarda teknoloji kullanımı ve uygulamalar: Gözlemler, sorunlar ve çözüm önerileri, Artı Eğitim, 123, 90-9, 2015.

[24] S. Turan, Teknolojinin Okul Yönetiminde Etkin Kullanımında Eğitim Yöneticisinin Rolü, Kuram ve Uygulamada Eğitim Yönetimi, Sayı: 30. 271-281, 2002.

[25] E. Usta, Ö. Korkmaz, Öğretmen adaylarının bilgisayar yeterlikleri ve teknoloji kullanımına ilişkin algıları ile öğretmenlik mesleğine yönelik tutumları, Uluslararası İnsan Bilimleri Dergisi, 7(1), 1335-1349, 2010.

[26] M. A. Sönmez, Meslek liselerinde örgüt kültürü, Kuram ve Uygulamada Eğitim Yönetimi, 45(45), 85-108, 2006.

[27] K. Yılmaz, Y. Ayaydın, Sosyal Bilgiler Öğretmenlerinin Öğretim Teknolojileri Kullanımına İlişskin Alt Yapılarının ve Yeterlilik Algılarının İncelenmesi Nitel Bir Çalışma, Abant İzzet Baysal Üniversitesi Eğitim Fakültesi Dergisi, 15(USBES Özel Sayısı I), 87-107, 2015.

[28] H. Yıldız, M. Sarıtepeci, S. S. Seferoğlu, FATïH projesi kapsamında düzenlenen hizmet-içi eğitim etkinliklerinin ögretmenlerin mesleki gelişimine katkılarının ISTE ögretmen standartları açısından incelenmesi, Hacettepe 
Üniversitesi Eğitim Fakültesi Dergisi/Hacettepe University Journal of Education, Özel Sayı(1), 375-392, 2013.

[29] E. İzci, M. Eroğlu, Eğitimde Teknoloji Kullanımı Kursu hizmetiçi eğitim programının değerlendirilmesi, International Journal of Human Sciences, 13(1), 1666-1688, 2016.

[30] S. Yavuz, E. A. Coşkun, Sınıf öğretmenliği öğrencilerinin eğitimde teknoloji kullanımına ilişkin tutum ve düşünceleri, Hacettepe Üniversitesi Eğitim Fakültesi Dergisi, 34(34), 2008. 